\title{
Aphrodisiac Activity of Ethanolic Extracts from the Fruits of Three Pepper Plants from Piperaceae Family
}

Idha Kusumawati ${ }^{1,2 *}$, Syailendra Mahatmaputra ${ }^{1}$, Rohman Hadi $^{1}$, Rohmania $^{1}$, Subhan Rullyansyah ${ }^{1}$, Helmy Yusuf ${ }^{1}$, Abdul Rahman ${ }^{1}$

${ }^{1}$ Department of Pharmaceutical Science, Faculty of Pharmacy, Universitas Airlangga, Surabaya, Indonesia

${ }^{2}$ Natural Product Drug Development and Discovery Research Group, Faculty of Pharmacy, Universitas Airlangga,

Surabaya, Indonesia

*Corresponding author: idha-k@ff.unair.ac.id

Submitted: 15 Juni 2021

Accepted: 27 Juli 2021

Published: 29 Agustus 2021

\begin{abstract}
Background: Pepper plants belong to the Piperaceae family with many pharmacological activities. The fruits of these plants have been widely used traditionally for various therapies, one of which is an aphrodisiac. Objective: The purpose of this study was to determine the aphrodisiac activity of the fruits of three pepper plants, Piper nigrum, Piper retrofractum, and Piper cubeba to prove their traditional use. Methods: The level of piperin, the active compound of plants from the family Piperaceae, was also determined in the ethanolic extract of those three fruits of the pepper plant. The aphrodisiac activity was determined by counting the number of introducing and mounting mice. The acute toxicity test of the extract was carried out according to the OECD-423 guidelines. Results: The ethanolic extract of Piper nigrum fruits had the highest piperin concentration, while the ethanolic extract of Piper retrofractum fruits had the highest aphrodisiac activity, according to the findings. During the entire duration of the acute toxicity study, no signs of toxicity or mortality were discovered.Conclusion: This study proves that all fruits of three species of pepper plants exhibit aphrodisiac activity. Furthermore, this study also shows that not only piperin is responsible for the aphrodisiac effect.
\end{abstract}

Keywords: aphrodisiac, herbal, medicine, piperine content, Piper sp

\begin{abstract}
Abstrak
Pendahuluan: Tanaman lada termasuk dalam famili Piperaceae yang memiliki banyak aktivitas farmakologi dan telah banyak digunakan secara tradisional untuk berbagai terapi, salah satunya sebagai afrodisiak. Tujuan: Penelitian ini bertujuan untuk mengetahui aktivitas afrodisiak ekstrak buah dari tiga tanaman yaitu Piper nigrum, Piper retrofractum, dan Piper cubeba untuk membuktikan kegunaan tradisionalnya. Metode: Kadar piperin, senyawa aktif tanaman dari famili Piperaceae, juga ditentukan dalam ekstrak etanol ketiga buah tanaman tersebut. Aktivitas afrodisiak ditentukan dengan menghitung introducing dan mounting dari mencit. Uji toksisitas akut dilakukan sesuai dengan pedoman OECD-423. Hasil: Berdasarkan uji yang dilakukan, ekstrak etanol buah Piper nigrum memiliki konsentrasi piperin tertinggi, sedangkan ekstrak etanol buah Piper retrofractum memiliki aktivitas afrodisiak yang paling tinggi. Tidak ada tanda-tanda toksisitas atau kematian yang ditemukan selama uji toksisitas akut. Kesimpulan: Ketiga tanaman lada ini memiliki sifat afrodisiak, seperti yang disarankan dalam penggunaan tradisionalnya. Namun, hasil penelitian juga menunjukkan bahwa piperin bukan satu-satunya senyawa dalam tanaman lada yang memiliki sifat afrodisiak.
\end{abstract}

Kata kunci: afrodisiak, herbal, kandungan piperin, Piper sp, medicine 


\section{INTRODUCTION}

Sexual dysfunction is a life-threatening emergency. This disorder affects $10 \%$ to $52 \%$ of men and $25 \%$ to $63 \%$ of women. Male sexual dysfunction like impotence and erectile dysfunction (ED) has become a very important health issue because it affects the quality of life. ED is a persistent inability to acquire or maintain a satisfying erection for sexual intercourse. This sexual dysfunction affects an estimated 20 - 30 million males or occurs in about 1 in 10 men, which increases with age and in people with diseases such as diabetes and heart disease. Psychological conditions and social problems such as stress, depression, and unhappiness are triggers that can cause ED (Erhabor \& Idu, 2017; Goel \& Kumar, 2020).

Aphrodisiac is something that can increase sexual desire. There are two types of aphrodisiacs, psychophysiological stimuli (visual, touch, smell, and aural) and food or drinks. Sildenafil (improves erection), Tadalafil (promotes erection), Addyi ${ }^{\circledR}$ (to increase sexual hypoactivity in women) are prescribed for sexual dysfunction. This compound can treat organic and psychological impotence. Sildenafil, the drug of choice for aphrodisiac, has a PDE5 inhibiting mechanism that can increase (eGMP) in the cavernous blood vessels resulting in muscle relaxation that increases erection. Several side effects of using sildenafil have been reported, such as flushing, headache, congestion, and dyspepsia. The withdrawal effect of sildenafil is a decrease in systemic systolic and diastolic arterial pressure and cardiac output, so it is contraindicated for patients using nitrate or nitric oxide donors. Sudden death in patients with coronary artery disease who use sildenafil raises concerns about its safety (Ganie et al., 2019; Patel et al., 2011, Patel et al., 2012).

Although sildenafil is still ubiquitous, various herbs are widely used and are very useful for treating erectile dysfunction for a long time. Various studies have proven that herbs have multiple activities related to erectile dysfunction, such as reducing intracellular $\mathrm{Ca} 2+$ concentrations, increasing testosterone levels, increasing cAMP expression, and relieving oxidative stress. Screening for aphrodisiac potential from plants needs to be done to obtain potential plants and isolated active compounds (Goel \& Kumar, 2020).

Various plants that are traditionally used as aphrodisiacs are plants in the Piperaceae family. One of the genera is Piper, which grows and is widespread in the pantropics. The piper plant is also known by the common name "pepper," with the characteristic of having an essential oil content so that it is included in the group of aromatic plants. Plants in the Piperaceae family are shrubs, vines, or trees. There are approximately 1000 species in the Piperaceae family, while there are about 300 species in the piper genus. Usually contains aromatic compounds and alkaloids. Pepper plants, Piper retrofractum Vahl., Piper nigrum L., and Piper cubeba L., are species belonging to the Piperaceae family. Fruits of the three Piper species are widely used in medicine with many pharmacological activities. They have been widely used traditionally for various therapies, one of which is an aphrodisiac (Durant-archibold et al., 2018; Salehi et al., 2019).

Piper retrofractum Vahl., known as Java chili, grows in Southeast Asia, especially in Indonesia, Malaysia, and Thailand. Traditionally the fruit is used for stimulants, carminatives, and tonics. $P$. retrofractum in Indonesia is used as a drink to improve sleep and aphrodisiac. This plant is cultivated commercially in various islands in Indonesia (Hasan et al., 2016; Rahmawati \& Bachri, 2012; Vinay et al., 2012). Piper nigrum L., or black pepper, has energetic, sweaty, carminative, and stimulant properties. Empirically used to cure colic, flatulence, dyspepsia, hemorrhoids, and as an aphrodisiac, especially for conditions of sexual weakness or desires for depression (Malini et al., 1999; Tajuddin et al., 2003). Piper cubeba L., known in Indonesia as kemukus, grows on Java, Sumatra, South Kalimantan, and other islands in the Indian Ocean. Traditionally, kemukus has been used to treat gonorrhea, dysentery, syphilis, abdominal pain, diarrhea, enteritis, and asthma. Like other pepper, kemukus is also used as an aphrodisiac (Elfahmi et al., 2007; Jamal et al., 2011).

Piperine, an alkaloid, is the main active compound that contributes to the activity of plants in the genus Piper. Piperine has various biological activities such as anti-inflammatory, antipyretic, analgesic, insecticide, immunotherapy, antitumor, anti-depressant, and anti-apoptosis (Vinay et al., 2012). Piperine and the isomer is a compound that causes a spicy taste in pepper. Piperine can increase the absorption of several compounds such as selenium, vitamin $B$, and $\beta$ carotene. In addition, Piperine also stimulates digestive enzymes, increases the secretion of biliary bile acids. Piperine also has hepatoprotective properties, inhibits lipid peroxidation and antifertility. Recent research shows that Piperine also affects mood and cognitive impairment (Vasavirama \& Upender, 2014).

Therefore, in this study, the aphrodisiac activity of the fruit extracts of $P$. retrofractum, $P$. nigrum and $P$. 
cubeba will be determined. The doses used of the three extracts were equivalent to $13 \mathrm{mg}$ of piperine obtained from preliminary studies, which have been shown to have aphrodisiac activity.

\section{MATERIALS AND METHODS \\ Materials}

The fruits of Piper retrofractum Vahl. (PR), Piper nigrum L. (PN), and Piper cubeba L. (PC), were obtained from a cultivated area in Madura Island, East Java, Indonesia. Voucher specimens were identified and deposited in the Pharmacognosy and Phytochemistry Laboratory, Faculty Pharmacy, Airlangga University.

The following reagents were of analytical quality: Piperine (Sigma-Aldrich, Singapore), Sildenafil (Pfizer). Solvents: Chloroform, n-Hexane, Methanol, Toluene, and Formic acid were purchased from Merck (Indonesia), unless otherwise specified. All chemicals and solvents were of analytical grade. TLC silica gel GF254 precoated plates were purchased from E-Merck. Tools

Linomat $\mathrm{V}$ autosampler, Automated developing chamber version 2, TLC scanner, visualizer, computer software (WinCats) and Video scan software (Camag, Muttenz, Switzerland).

\section{Method}

\section{Plant extraction}

The fruits were washed and dried for three days in a $40^{\circ} \mathrm{C}$ food dehydrator. Dry fruits were powdered and kept in a tight container until needed. Dry powdered fruit (100 g) extracted by microwave accelerated extraction method. The plant material was extracted in a microwave (30\% generator power) for one minute with $96 \%$ ethanol (plant: solvent, $1: 10, w / v)$. To obtain the crude ethanolic extract, the extracts were filtered, concentrated, and dried by evaporating the solvent under reduced pressure.

\section{Determination of piperine content}

Determination of piperine content in all extracts used a validated TLC-Densitometric method. TLC silica gel GF254 precoated plates were used in this method with toluene-methanol-formic acid (10: 1: 0.1) as mobile phase. Stock solution using piperine standard at $1.0 \mathrm{mg} / \mathrm{mL}$ and the standard solution was derived from stock solution became five concentrations and applied on TLC plate to get the final amounts of 400 $800 \mathrm{ng} / \mathrm{spot}$. Application of sample was performed using Linomat $\mathrm{V}$ autosampler. Each extract solution in methanol (PC $100 \mu \mathrm{g} / \mathrm{mL}$, PR $100 \mu \mathrm{g} / \mathrm{mL}$ and PC $1000 \mu \mathrm{g} / \mathrm{mL}$ ) were applied $1.0 \mu \mathrm{L}$ on a TLC plate with a $7.0 \mathrm{~mm}$ bandwidth using a Linomat $\mathrm{V}$ syringe, in triplicate. TLC plate was developed for $8 \mathrm{~cm}$ in the automated developing chamber. The densitometric analysis was performed on a TLC scanner in the absorbance mode at $340 \mathrm{~nm}$. The piperine content in each extract was determined by the peak area using linear regression and was expressed in $\mathrm{mg} / \mathrm{g}$ of the extract.

\section{TLC profile characterization}

TLC profile was performed with the same condition as the method for piperine content determination, except the use of Chloroform-Hexane-Methanol-Formic acid (8:4:0.5:0.25 v/v) as a solvent system. After developing and drying the plate, the plate was photographed using a visualizer under $365 \mathrm{~nm}$ and uploaded to the WinCats software. Densitometric scanning was carried out and operated by Video scan software.

\section{In vivo aphrodisiac assay}

The research was designed based on the ethical standards for animal use and was approved by the Airlangga University Ethical Committee of Animal Experimentation. This experiment was done using the modified method described by Balamurugan et al. (2010). Forty-eight male mice (ICR), aged 3 months and 20-25 g weight, were randomly grouped into six groups (eight animals in a group): control group, Sildenafil group, PR group, PN group, PC group, and P (piperine) group. Female mice's acceptance was validated before the test by introducing them to male mice. After fasting overnight, all mice received a single dose of oral treatment: control group received vehicle (Natrium CMC $0.05 \%) 20 \mathrm{~mL} / \mathrm{Kg}$, Sildenafil group received the standard drug-Sildenafil citrate $5 \mathrm{mg} / \mathrm{kg}$ (Erhabor \& Idu, 2017), P group received $13 \mathrm{mg}$ piperine/kg, PR group, $\mathrm{PN}$ group and PC group received extract containing 13 $\mathrm{mg}$ piperine $/ \mathrm{Kg}$. The amount of extract used from the three samples was calculated based on the piperine content in each sample. Male mice were inserted into the glass cage, and 30 minutes later, female mice were inserted and performed the recording process. After 1 hour, the female mice were separated by male mice for 1 hour, then put back into the glass enclosure and recorded for up to 1 hour. All the experimental process is done at noon at $09.00-12.00$ with room temperature $26-27^{\circ} \mathrm{C}$, then counted the number of introducing and mounting.

\section{Acute toxicity studies}

Acute toxicity of the extract was carried out in ICR rats according to OECD-423 guidelines. Grouping of rats was carried out randomly into four groups $(\mathrm{N}=3)$ : normal, PR, PN, and PC. After fasting overnight, all animals are given a single dose of $5 \mathrm{mg} / \mathrm{Kg}$. 
Observations were made for 2 hours, then 4 hours to see any signs of poisoning or death. If there is no mortality, one more animal is given the same dose. If no deaths are observed at this dose, the same procedure will be repeated for 50, 300, and $2000 \mathrm{mg} / \mathrm{Kg}$ extract levels in a separate new group. Changes in behavior observed were: hyperactivity, ataxia, tremor, convulsions, saliva, diarrhea, lethargy, sleep, and coma. The animals continued to be monitored for up to 14 days after drug administration to determine the delayed death (OECD, 2001).

\section{Statistical analysis}

The results are expressed as means \pm SD (standard deviation of the mean). Statistical differences between groups were estimated using one-way analysis of variance (ANOVA) with Duncan's test and were considered statistically significant at $p<0.05$.

\section{RESULTS AND DISCUSSION}

The ethanolic extract yields obtained by microwave accelerated extraction of the fruits of three Pepper species were about $14-16 \%$ (w/w). Results for the quantitative analysis of the piperine in each extract are shown in Tables 1.

In table 1 shows that piperine content in ethanolic extract of PN higher than two others, PR and PC. A number of extracts containing $13 \mathrm{mg}$ piperine were used in the in vivo aphrodisiac activity test. As a result, the amount of extract in each sample varies (PR, $100 \mathrm{mg}$ extract/kg; PN, $24 \mathrm{mg}$ extract/kg; PC $4333 \mathrm{mg}$ extract $/ \mathrm{kg}$ ), but the piperine content for in vivo study remains consistent. The profile metabolite content in each extract (PC, PR and PN) can be seen in Figure 1.

Table 1. Ethanolic extract yield and piperine content

\begin{tabular}{lcc}
\hline & Extract yield $(\mathrm{g})$ & Piperine content $(\mathrm{mg} / \mathrm{g})$ \\
\hline$P$. retrofractum $(\mathrm{PR})$ & 14.4 & $13.1 \pm 0.32^{\mathrm{b}}$ \\
$P$. nigrum $(\mathrm{PN})$ & 16.28 & $54.1 \pm 0.47^{\mathrm{a}}$ \\
$P$. cubeba $(\mathrm{PC})$ & 13.94 & $0.3 \pm 0.01^{\mathrm{c}}$ \\
\hline
\end{tabular}

Values are expressed as mean \pm SEM $(n=3)$; means in the same column followed by different letters $(\mathrm{a}, \mathrm{b}, \mathrm{c})$ are significantly different at $p<0.05$ using Duncan's tests.
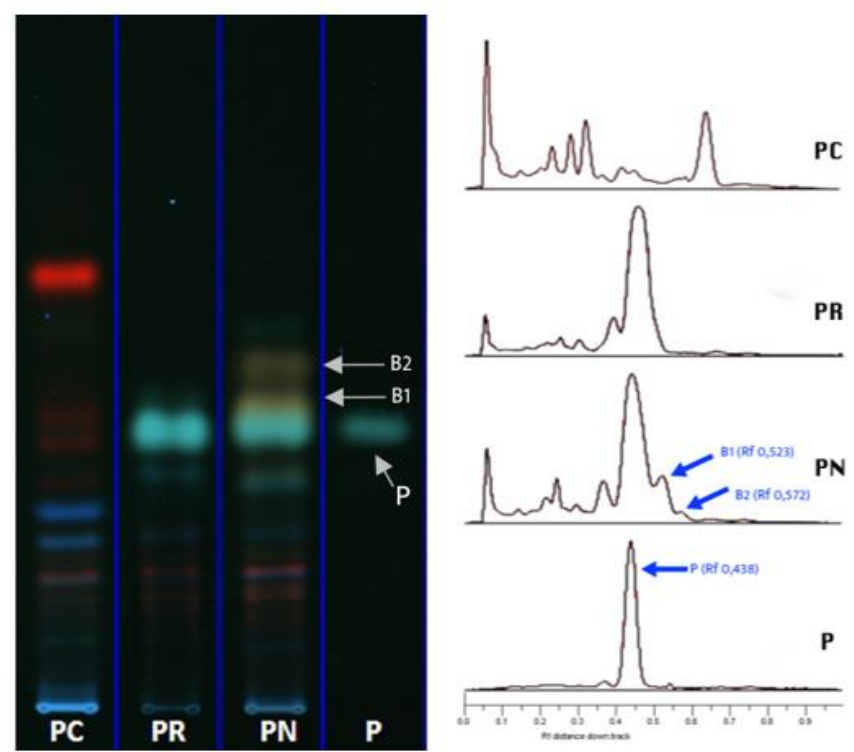

Figure 1. TLC profiles of PC, PR, PN and P. TLC plate was developed in Chloroform-Hexan-Methanol-Formic acid (8:4:0.5:0.25) and was visualized the spot fluorescence color under $365 \mathrm{~nm}$. PC, ethanolic extract of $P$. cubeba fruits; PR, ethanolic extract of $P$. retrofractum fruits; PN, ethanolic extract of $P$. nigrum fruits; P, piperine; B1, brown spot 1 ;

B2. Brown spot 2.

In Figure 1 showed that Chloroform-HexaneMethanol-Formic acid (8:4:0.5:0.25) gave the best chromatographic resolution. The TLC profiles showed that PC, PR and PN had a piperine spot (P, green spot, Rf 0.438), but the intensity of that spot was too low in
PC. The chromatogram profile between $\mathrm{PR}$ and $\mathrm{PN}$ is almost the same but there is two brown spots (B1, Rf 0.523 and $\mathrm{B} 2,0.572$ ) which makes the difference, while the chromatogram profile of the PC is very different when compared to PR and PN. 
During the whole period of the acute toxicity investigation, no indicators of toxicity or mortality were discovered. All extracts were found to be safe up to 2000 $\mathrm{mg} / \mathrm{kg}$. According to OECD-423 guidelines for acute oral toxicity, an LD50 dose of $2000 \mathrm{mg} / \mathrm{kg}$ and above is categorized as unclassified.

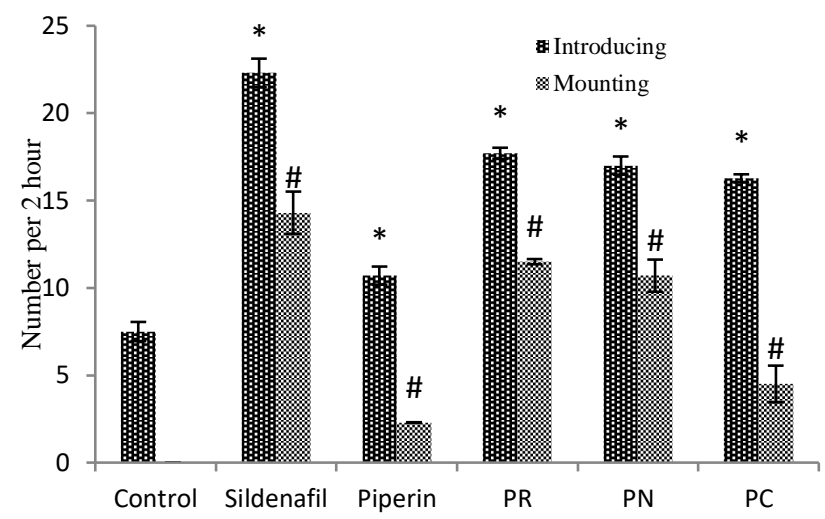

Figure 2. Effect of various treatments on the aphrodisiac activity. Values are expressed as mean \pm SEM $(n=8)$; $p<0.05$ using Duncan's tests. *P $<0.05$ versus the number of introducing of control group; \#P $<0.05$ versus the number of mountings of control group

Aphrodisiac increases sex drive and/or sexual pleasure or can arouse sexual desire or libido. For this reason, the parameters used in this study are the number of introducing and mounting of male mice against female mice. The introduction is defined as an attitude to initiate sexual activity, which involved licking and sniffing of the female anogenital organs. Mounting is defined as a copulatory position but fails to reach the vaginal entrance. Mounting behavior of male mice is usually by climbing from behind of female mice, intending to transfer from one organ to another (Balamurugan et al., 2010; Land \& McGill, 1967; Singh et al., 2013). The female mice used in the aphrodisiac activity test were receptive female mice that passed the female animal acceptance test. The acceptance test of female animals is carried out to ensure that these female animals are mature and ready to mate. The aphrodisiac test used three receptive female animals for one male animal (Balamurugan et al., 2010; Singh et al., 2013).

The number of introducing and mounting of each group are summarized in figure 2 . All of the data has a significant difference $(p<0.05)$ in each group. The PR group, PN group, and PC group received a single dose of extracts containing $13 \mathrm{mg}$ piperine $/ \mathrm{Kg}$. The $\mathrm{P}$ group also received $13 \mathrm{mg}$ piperine $/ \mathrm{kg}$. All samples (PR, PN, $\mathrm{PC}$, and $\mathrm{P}$ ) could stimulate the introduction and mounting of male mice and showed aphrodisiac activity. This study has proved that these three pepper plants have aphrodisiac activity according to their traditional use. Although each group received the same amount of piperine, increasing aphrodisiac activity was different, PR $>$ PN $>$ PC $>$ P, respectively. Because piperine levels in each extract were different, the amount of extract administered to each group was varied ( $\mathrm{PC}>\mathrm{PR}>\mathrm{PN}$ ). The $\mathrm{PN}$ group received $24 \mathrm{mg}$ extract/Kg, the $\mathrm{PR}$ group $100 \mathrm{mg}$ extract $/ \mathrm{Kg}$, and the $\mathrm{PC}$ group $4333 \mathrm{mg}$ extract $/ \mathrm{kg}$. The amount of extract given, however, did not correspond to its aphrodisiac activity.

Piperine was found to have lower aphrodisiac activity than the three extracts. The PN extract's chromatogram profile revealed the presence of two compounds (B1 and B2) that were absent from the PR extract's chromatogram profile. Despite this, PR's aphrodisiac activity was higher than PN's. The chromatogram profile of the PC extract revealed compounds that were absent from the PR and PN extracts. Compounds that were not present in the PR and PN extract chromatogram profiles were found in the PC extract chromatogram profile. The amount of PC extract administered was high, but it had little aphrodisiac activity, and the number of components with a synergistic effect is thought to be small. The difference of the constituent in extract causes differences in the aphrodisiac activity of each extract, so it can be assumed that piperine is not the only constituent responsible for the aphrodisiac activity of the extract; other compounds may have a synergistic effect.

\section{CONCLUSION}

This research has successfully proven that all fruits of three species of pepper plants have aphrodisiac activity according to their traditional usage. This finding also reveals that aphrodisiac activity is not only caused by piperine, thus further research is also needed to 
determine which compounds are responsible for the aphrodisiac effect of pepper plant fruits.

\section{ACKNOWLEDGMENT}

This work was supported by a research grant from the Faculty of Pharmacy, Universitas Airlangga.

\section{REFERENCES}

Balamurugan, G., Muralidharan, P. \& Polapala, S. (2010). Aphrodisiac Activity and Curative Effects of Pedalium murex (L.) Against Ethanol-Induced Infertility in Male Rats. Turky Journal of Biology; $34 ; 153-163$.

Durant-archibold, A. A., Santana, A. I. \& Gupta, M. P. (2018). Ethnomedical Uses and Pharmacological Activities of Most Prevalent Species of Genus Piper in Panama: A Review. Journal of Ethnopharmacology; 217; 63-82.

Elfahmi, R. K., Batterman, S., Bos, R., Kayser, O., Woerdenbag, H. J., \& Quax, W. J. (2007). Lignan profile of Piper cubeba, an Indonesian Medicinal Plant. Biochemical Systematics and Ecology; 35; 397-402.

Erhabor, J. O., \& Idu, M. D. (2017). Aphrodisiac Potentials of the Ethanol Extract of Aloe barbadensis Mill. Root in Male Wistar rats. BMC Complementary and Alternative Medicine; 17; 110.

Ganie, A. H., Tali, B. A., Shapoo, G. A., Nawchoo, I. A., \& Khuroo, A. A. (2019). Ethno-survey of Traditional Use of Plants as Aphrodisiacs in Kashmir Himalaya, India. Journal of Herbal Medicine; 17-18; 100256.

Goel, B., \& Kumar, M. N. (2020). Aphrodisiac Herbal therapy for Erectile Dysfunction. Archives of Pharmacy Practice; 11; 1-6.

Hasan, A. E. Z., Mulia, K., Setiyono, A. \& Silip, J. J. (2016). Antiproliferation Activities of Indonesian Java Chili, Piper retrofractum Vahl., Against Breast Cancer Cells (MCF-7). Der Pharmacia Lettre; 8; 141-147.

Jamal, J. A., Ghafar, Z. A. \& Husain, K. (2011). Medicinal Plants used for Postnatal Care in Malay Traditional Medicine in the Peninsular Malaysia. Pharmacognosy Journal; 3; 15-24.

Land, R. \& McGill, T. E. (1967). The Effects of the Mating Pattern of the Mouse on the Formation of Corpora Lutea. Journal of Reproduction and Fertility; 13; 121-125.

Malini, T., Arunakaran, J., Aruldhas, M. \& Govindarajulu, P. (1999). Effect of Piperine on the
Lipid Composition and Enzymes of the PyruvateMalate Cycle in the Testis of the Rat in Vivo. Biochemistry and Molecular Biology International; 47; 537-545.

OECD. (2001). Acute Oral Toxicity - Acute Toxic Class Method in OECD Guideline for Testing of Chemicals. Paris: OECD.

Patel, D. K., Kumar, R., Laloo, D., Sairam, K. \& Hemalatha, S. (2012). Aphrodisiac Activity of Ethanolic Extract of Pedalium murex Linn fruit. Asian Pacific Journal of Tropical Biomedicine; 2; 1568-1571.

Patel, D. K., Kumar, R., Prasad, S. K. \& Hemalatha, S. (2011). Pharmacologically Screened Aphrodisiac Plant-A Review of Current Scientific Literature. Asian Pacific Journal of Tropical Biomedicine; 1; S131-S138.

Rahmawati, N. \& Bachri, M. S. (2012). The Aphrodisiac Effect and Toxicity of Combination Piper retrofractum L., Centella asiatica, and Curcuma domestica Infusion. Health Science Indonesia; 3; 19-22.

Salehi, B., Zakaria, Z. A., Gyawali, R., Ibrahim, S. A., Rajkovic, J., Shinwari, Z. K., Khan, T., SharifiRad, J., Ozleyen, A., Turkdonmez, E., Valussi, M., Tumer, T. B., Fidalgo, L. M., Martorell, M., \& Setzer, W. N. (2019). Piper Species: a Comprehensive Review on Their Phytochemistry, Biological Activities and Applications. Molecules; 24; 1364.

Singh, R., Ali, A., Jeyabalan, G., Semwal, A. \& Jaikishan. (2013). An Overview of the Current Methodologies Used for Evaluation of Aphrodisiac Agents. Journal of Acute Disease; 2; 85-91.

Tajuddin, A., S., Latif, A. \& Qasmi, I. A. (2003). Aphrodisiac Activity of 50\% Ethanolic Extracts of Myristica fragrans Houtt. (Nutmeg) and Syzygium aromaticum (L) Merr. \& Perry. (Clove) in Male Mice: a Comparative Study. BMC Complementary and Alternative Medicine; 3; 6.

Vasavirama, K. \& Upender, M. (2014). Piperine: a Valuable Alkaloid from Piper Species. International Journal of Pharmacy and Pharmaceutical Sciences; 6; 34-38.

Vinay, S., Renuka, K., Palak, V., Harisha, C. R. \& Prajapati, P. K. (2012). Pharmacognostical and Phytochemical Study of Piper longum L. and Piper retrofractum Vahl. Journal of Pharmaceutical and Scientific Innovation; 1; 6266. 